\title{
Guidelines to sustainable planning and restoration of lakes
}

\author{
G. Mosaad, A. Mamdouh, B. Gomaa \& E. El-Halwagy \\ Department of Architectural Engineering and Environmental Design, \\ Arab Academy for Science and Technology and Maritime Transport, \\ Alexandria, Egypt
}

\begin{abstract}
A lake is an important feature of landscape; it is as important to the ecosystem as to the people who live around them. However, a large number of lakes recently have been lost due to human activities and what remains is at risk of degradation. A lot of countries around the world have many lakes that are not only suffering from pollution problems but also suffer from heavy encroachment from industrial, urban and agricultural development. There are many phases and ways to solve the problem; first to stop abuse, then restoration and finally, monitoring and maintenance. The main aim of the paper is to develop a means of restoring valuable lakes using sustainable urban planning guidelines and green infrastructure strategies. Green infrastructure refers to natural and engineered systems that act as a living infrastructure; it integrates natural vegetation and soils into the community's fabric through a variety of techniques, approaches, technologies and practices. The importance of green infrastructure goes beyond restoration of lakes and their buffer, and extends to social, economic and environmental integrity. Research methodology includes literature review and analytical example. Research is expected to conclude in the guidelines of lakes restoration and urban planning strategies.

Keywords: lakes restoration, green infrastructure, sustainable planning, waterfront planning.
\end{abstract}

\section{Introduction}

Lake is a very general term used for standing water, large enough in area and depth, but irrespective of its hydrology, ecology and other features. The US 
national lake conservation program considers lakes as "standing water bodies which have a minimum water depth of $3 \mathrm{~m}$, generally cover a water spread of more than ten hectares, and have no or very little aquatic vegetation" [1]. Healthy lakes and their buffers not only provide people with environmental benefits but also influence the quality of life and economy, through several points; storing large amounts of water, refill groundwater, positively influence water quality of downstream water courses, preserve the biodiversity and habitat of the area, provide the recreational spaces, respected by many people for their historical and traditional values, it can be used as a water supply for industrial and irrigation source for agriculture lands finally it can sustain a healthy balance of aquatic life and that help in support the socio-economic needs. [2]. Natural lakes are not plain storages of water; they are dynamic ecosystems with composite interactions between geology, geomorphology, climate, hydrology and biology [1].

\section{Physical zones of lakes}

Lakes consist of four zones based on their depth and distance from the shore. The zones in a lake include the littoral zone, limnetic zone, profundal zone and benthic zone [3] (Fig. 1).

Littoral zone is shallow sunlit water that contains most plant life, while limnetic zone is the open water exposed to sunlight, profundal zone is the deep open water where it is too dark for photosynthesis, and benthic zone is the bottom of the lake [3].

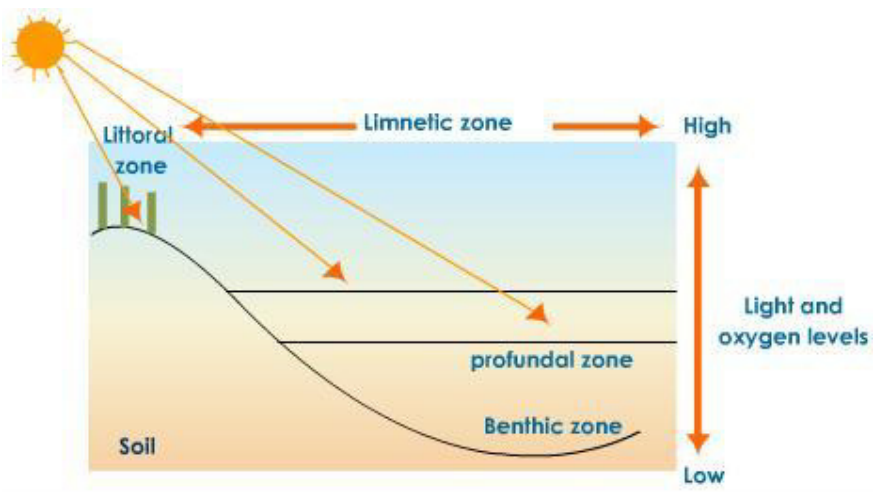

Figure 1: $\quad$ The four zones of lakes (source [4]).

\section{Planning of lakes' buffer}

It is the area extending outward perpendicularly from the top of the bank of a natural or constructed channel or watercourse. This buffer consists of three subzones after which comes the construction zone. The three zones are; protection zone, separation zone and transition zone [5] (Fig. 2). 


\subsection{Waterfront zone}

A zone that protects the physical characteristics of the lake's ecosystem, 15m$22.5 \mathrm{~m}$ wide, measured from the outer edge of the lake's habitat. This zone provides several functions; it allows flood control, utility rights of ways, foot paths (1.8m maximum) and road crossing such as bridges. On the other hand in this zone mechanized logging, clear cutting trees, removal of vegetation is prohibited, also $15 \mathrm{~m}$ wide of the zone should be fertilizer free then the rest of the space only low phosphate and accessory structure must be set back at least $7.5 \mathrm{~m}[6]$.

\subsection{Middle zone}

An area that provides distance between upland development and protection zone. The width here is from $15 \mathrm{~m}$ to $20 \mathrm{~m}$. However its confederation are; allowable points; limited recreational uses and primary structure, on the other hand limitations are, $50 \%$ of the zone should remain in undisturbed state, $20 \%$ only impervious surfaces, no mechanized logging and a minimum of $50 \%$ of the tree canopy should remain undisturbed [6].

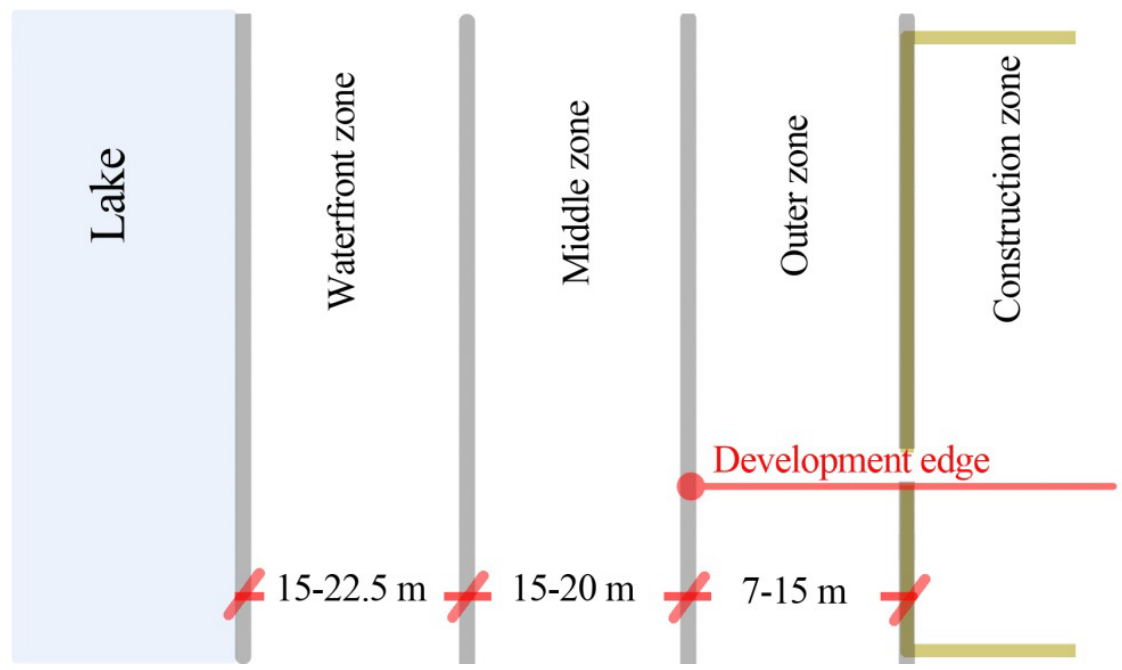

Figure 2: $\quad$ Zones of lakes’ buffer.

\subsection{Outer zone}

This zone prevents encroachment and filters the backyard runoff. Its width is not less than $7 \mathrm{~m}$ and not more than $15 \mathrm{~m}$. This zone has the following design considerations which are; it could be backyards, includes streets, and pedestrian walkways, on and off street parking, while the limitation include; only $20 \%$ of the constructed surfaces could be impervious surfaces [6]. 


\section{Principles of sustainable waterfront planning}

There are ten principles approved in the conference of urban 21; secure the quality of water and the environment, revitalization is an ongoing process, waterfronts are part of the existing urban fabric, the historical identity gives character, mixed use is a priority, public access is a prerequisite, public participation is an element of sustainability, planning in public private partnership speeds process, waterfront is long term project and waterfronts profit from international networking [7].

\section{Green infrastructure planning principles}

Benedict and McMahon in 2002 [8] mentioned seven principles as critical to the success of green infrastructure initiatives. These principles provide an approach and framework for conservation that benefit people, wildlife and economy. Principles include; 1- green infrastructure should be the framework for conservation and development; 2- design and plan green infrastructure before development; 3- linkage is key; 4- green infrastructure functions across multiple jurisdiction and different scales; 5- green infrastructure is grounded in sound science and land use planning theories and practices; 6- green infrastructure is a critical public investment; 7- finally green infrastructure involves diverse stakeholders.

Also northwest Michigan council [9] of government in 2008 added four different principles; the context matters, green infrastructure affords benefits to nature and people, green infrastructure requires making connections to activities within and beyond the community and finally green infrastructure requires longterm commitment.

In 2006 Benedict and McMahon [10] in their book linking landscapes mentioned that the principles can be; support native species, maintain natural ecological process, sustain air and water resources and contribute to the health and quality of life for communities and people.

Table 1 indicates the relationship and similarities between principles of sustainable waterfront and those of green infrastructure.

\section{Green infrastructure techniques}

Techniques of green infrastructure include; permeable pavement, vegetated swale, restores wetlands, urban fortes, infiltration trench, rain garden, rain barrel, down spout disconnection and green roof. Some of the techniques achieved all restoration benefits while others achieved only few.

The benefits are; slower rate of runoff, infiltration, retention, detention and water quality control as shown in table 2 . 
Table 1: $\quad$ Relationship between the principles of sustainable waterfront and the principles of green infrastructure.

\begin{tabular}{|c|c|}
\hline $\begin{array}{l}\text { Principles of sustainable } \\
\text { waterfront planning }\end{array}$ & Green infrastructure principles \\
\hline $\begin{array}{l}\text { 1- Secure the quality of water } \\
\text { and environment. }\end{array}$ & $\begin{array}{l}\text { Green infrastructure is } \\
\text { grounded in sound science } \\
\text { and land use planning } \\
\text { theories and practices. } \\
\text { - Sustain air and water } \\
\text { resources }\end{array}$ \\
\hline $\begin{array}{l}\text { 2- Re-vitalization is an ongoing } \\
\text { process. }\end{array}$ & $\begin{array}{l}\text { Green infrastructure should } \\
\text { be the framework for } \\
\text { conservation and } \\
\text { development }\end{array}$ \\
\hline $\begin{array}{l}\text { 3- Water-fronts are part of the } \\
\text { existing urban fabric. }\end{array}$ & $\begin{array}{ll}\text { - } & \text { Context matter } \\
\text { - } & \text { Maintain natural ecological } \\
& \text { process } \\
\text { - } & \text { Linking is key }\end{array}$ \\
\hline $\begin{array}{l}\text { 4- The historic identity gives } \\
\text { character. }\end{array}$ & $\begin{array}{l}\text { The socio economic impact } \\
\text { of green infrastructure }\end{array}$ \\
\hline 5- Mixed use is a prerequisite. & $\begin{array}{l}\text { - Green infrastructure requires } \\
\text { making connections to } \\
\text { activities within and beyond } \\
\text { the community } \\
\text { - } \quad \text { Land use planning }\end{array}$ \\
\hline 6- $\quad$ Public access is a priority. & - $\quad$ Linking is key \\
\hline $\begin{array}{l}\text { 7- Public participation is an } \\
\text { element of sustainability. }\end{array}$ & $\begin{array}{ll}\text { - } & \text { Green infrastructure is a } \\
\text { critical public investment } \\
\text { - } \\
\text { Green infrastructure } \\
\text { involves diverse } \\
\text { stakeholders }\end{array}$ \\
\hline 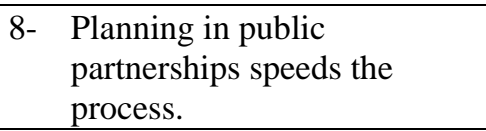 & $\begin{array}{l}\text { Design and plan green } \\
\text { infrastructure before } \\
\text { development }\end{array}$ \\
\hline $\begin{array}{l}\text { 9- Water-front is long term } \\
\text { projects. }\end{array}$ & $\begin{array}{l}\text { - Green infrastructure requires } \\
\text { long-term commitment }\end{array}$ \\
\hline
\end{tabular}


Table 2: $\quad$ Green infrastructure techniques and benefits.

\begin{tabular}{|l|c|c|c|c|c|}
\hline & $\begin{array}{l}\text { Slower } \\
\text { rate of } \\
\text { runoff }\end{array}$ & Infiltration & Retention & Detention & $\begin{array}{c}\text { Water } \\
\text { quality } \\
\text { control }\end{array}$ \\
\hline $\begin{array}{l}\text { Permeable } \\
\text { pavement }\end{array}$ & $\checkmark$ & $\checkmark$ & $\checkmark$ & $\checkmark$ & $\checkmark$ \\
\hline $\begin{array}{l}\text { Vegetated } \\
\text { swales }\end{array}$ & $\checkmark$ & $\checkmark$ & $\checkmark$ & $\checkmark$ & $\checkmark$ \\
\hline $\begin{array}{l}\text { Restores } \\
\text { wetlands }\end{array}$ & $\checkmark$ & $\checkmark$ & $\checkmark$ & & $\checkmark$ \\
\hline Urban fortes & $\checkmark$ & & $\checkmark$ & & $\checkmark$ \\
\hline $\begin{array}{l}\text { Infiltration } \\
\text { trench }\end{array}$ & $\checkmark$ & $\checkmark$ & $\checkmark$ & $\checkmark$ & $\checkmark$ \\
\hline Rain garden & $\checkmark$ & $\checkmark$ & $\checkmark$ & $\checkmark$ & $\checkmark$ \\
\hline Rain barrel & & & & & \\
\hline Green roof & $\checkmark$ & & $\checkmark$ & & \\
\hline $\begin{array}{l}\text { Down spout } \\
\text { disconnection }\end{array}$ & $\checkmark$ & $\checkmark$ & & & \\
\hline
\end{tabular}

\section{Waterfront land uses}

There are different types of land uses on water front area; in [12] nine different waterfronts development agreed a $1000 \mathrm{ft} \quad(304.8 \mathrm{~m})$ buffer to include the following; 1 - Recreational areas such as; bird watching, fishing, hiking, boating or canoeing and kids have a propensity to want to frolic and play in wetlands. [11]. 2 - Residential; low density, high density, multi-family and planned for high density. 3 - Commercial; general commercial, commercial hospitality, business district, mixed use, professional offices and marine commercial. 4 - Industrial area and others such as public facilities [12].

\section{Examples}

\subsection{Charlevoix, Michigan}

Charlevoix Lake is located in northwest Lower Michigan, its area is two square miles $\left(5.18 \mathrm{Km}^{2}\right)$. The lake has a population of 2513 and its high seasonal population is tourist and resort destination. The area of the buffer is $1000 \mathrm{ft}$ (304.8m) according to the agreement of; Charlevoix, Manistee, Manistique, Marquette, Monroe, Muskego, Ontonagon, Port Huron, Saugatuck and Sault Ste. Marie [12].

The total frontage is 7.0 miles; including $28 \%$ residential areas, $20 \%$ commercial, $49 \%$ open spaces and 3\% others [12] (Fig. 3). 


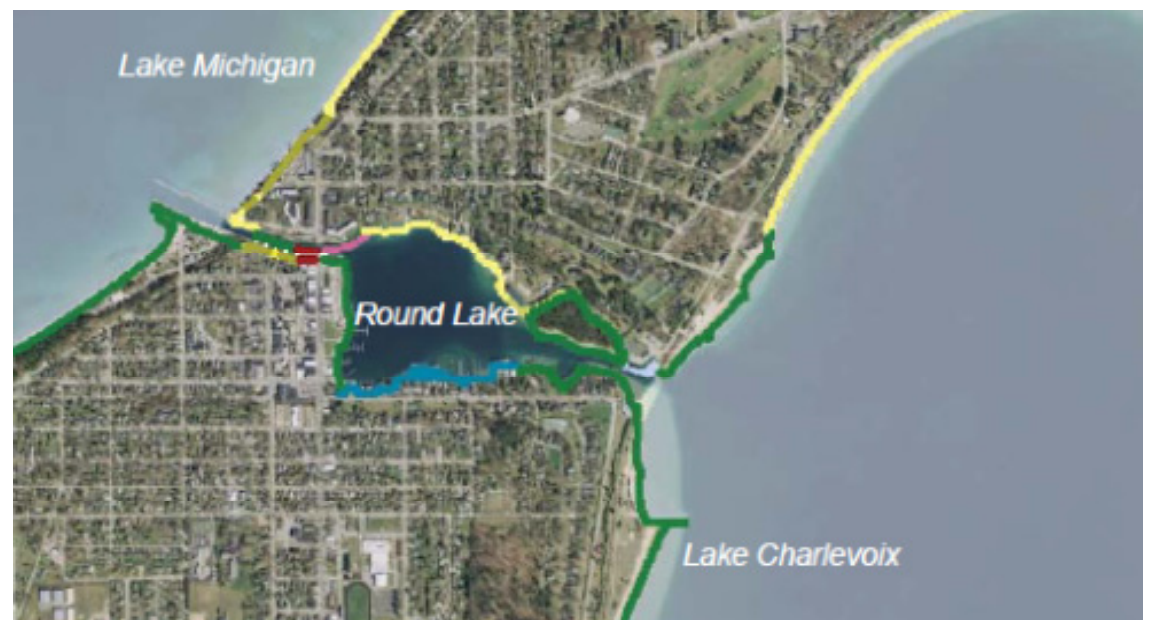

Figure 3: Waterfront zoning-frontage (source [12]).
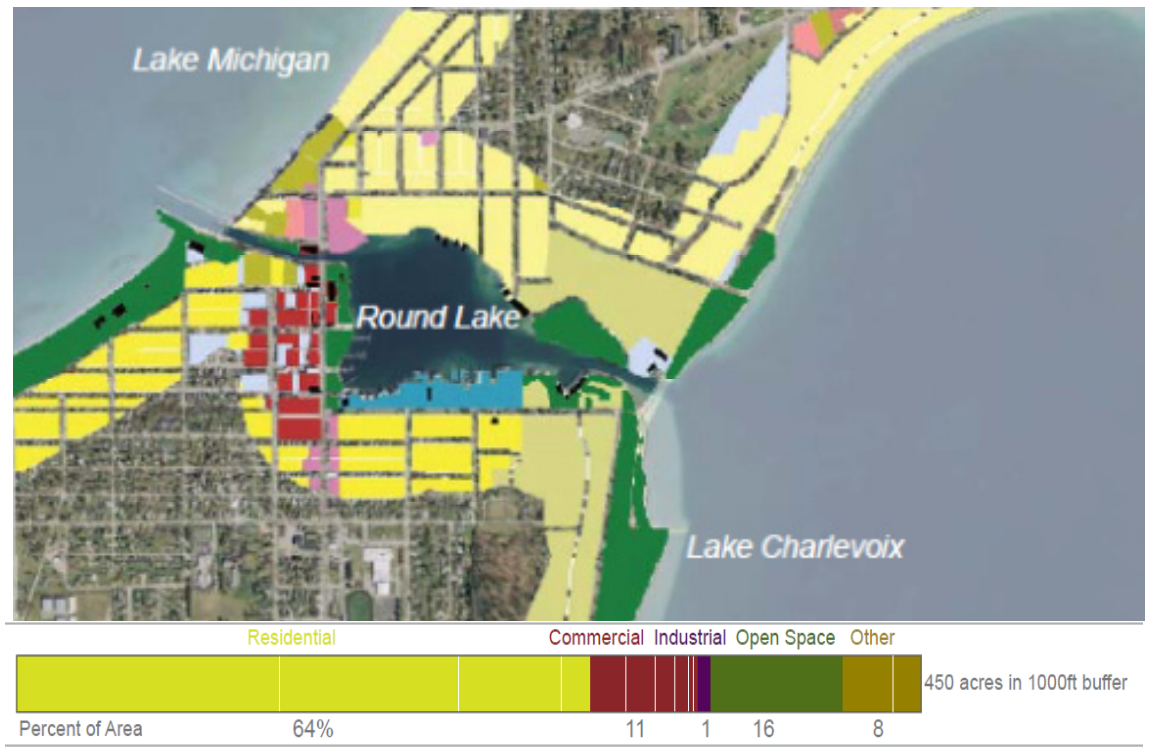

Figure 4: $\quad$ Waterfront zoning $-1000 \mathrm{ft}$ buffer (source [12]).

However the same buffer has 450 acres, split into 64\% residential uses, 11\% commercial, $1 \%$ industrial, $16 \%$ open spaces and $8 \%$ others [12] (Fig. 4). This gives the ration between the frontage and the area of different land uses in the buffer; a factor that shows the priority of each one of them on facing the lake. Residential land use scores 0.4 , commercial 1.8, industrial 0, open spaces 3 and others 0.3 . That shows that the first priority is to the open spaces, and second commercial, third residential then others. 


\subsection{Ontario Lake, Toronto, Canada}

Toronto, on the north shore of Lake Ontario, it is the largest of Canada's urban centers. It is the hub of the nation's commercial, financial, industrial, and cultural life, and is the capital of the zone of Ontario.

According to Dill and Bedford [13], the development of the lakefront of Oriento will bring a lot of benefits to the city of Toronto. Over 40000 new housing units can create homes for more than 68000 people. Commercial development of over 900000 square meters. New waterfront transportation and tourism infrastructure by creating a huge park act as green infrastructure which makes a lot of activities for Canadians and tourists. However Toronto acts as a getaway to the nation for commerce culture and tourism. That makes the importance of its development depending on Ontario waterfront development.

Toronto waterfront divided into several parts; the park, port lands, west don lands, exhibition place, central bay front and east bay front (Fig. 5).

The study here will be on east bay-front as an example for the planning of Toronto waterfront zones. Figure 6 shows the priority of each part. It shows the high accessibility between the city and the shoreline. However, of the buildings on the shoreline most of them mixed use. Also the green areas and open spaces take their places.

The redevelopment of the east bay-front implementing the design direction provided in the precinct plan. It is conformity with the principles of the precinct plan which are; a vibrant mixed use neighbourhood, active ground floors,

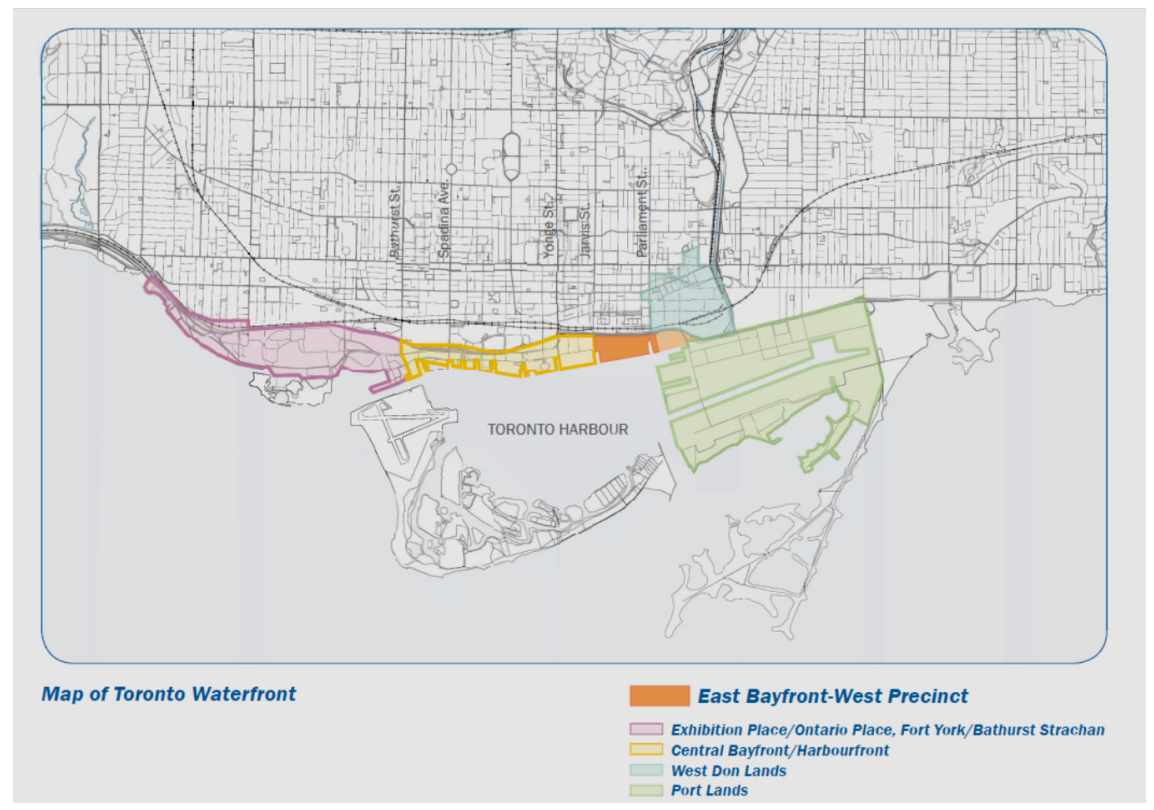

Figure 5: $\quad$ Toronto waterfront parts (source [14]). 


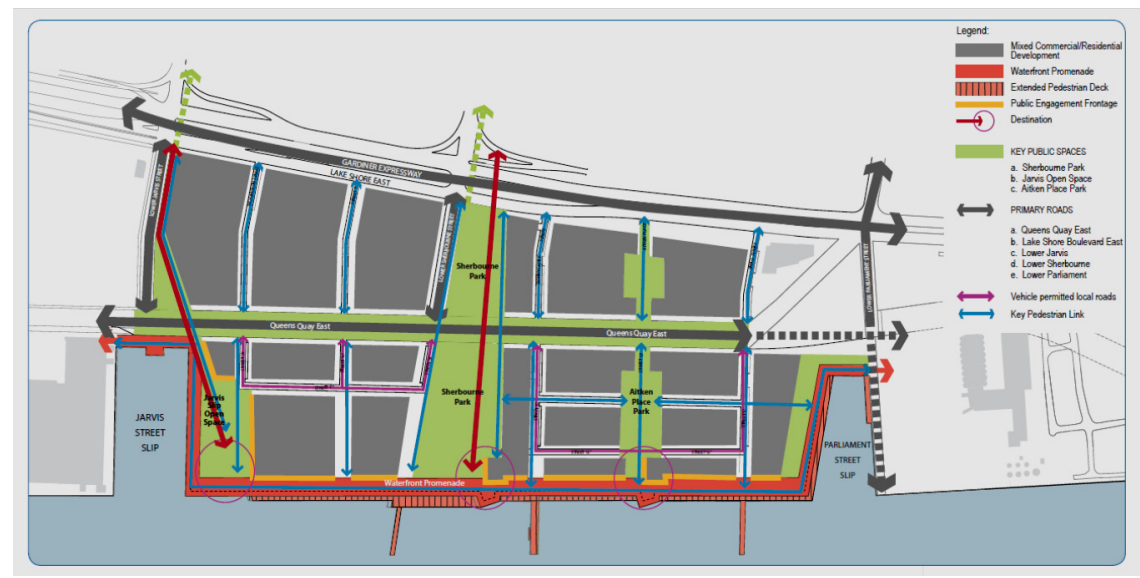

Figure 6: The east bay-front organizing (source [14]).

diversity of connected open spaces, network of streets, passages and connections, a mix of uses within flexible development parcels and finally visual and physical connections to the waterfront from the city [14].

\section{Discussion}

Previous effort would lead to a combined table, which could be used as guidelines and assessment of green lake restoration and urban planning as shown in Table 3.

The table shows the characteristics of each zone then the green infrastructure techniques and finally the land uses of each area. However the linking are; 1 Green linking which could be achieved through the intensive use of open spaces in waterfront zone, permeable walkways in middle zone and quality streets in both outer zone and construction zone (green ways and special urban spaces should also be utilized in the construction area). 2 - Public transportation which only appears in the outer zone and construction zone. 3 - Pedestrian; in waterfront zone its accepted $1.8 \mathrm{~m}$ maximum footpath, then in middle zone appear as a direct paths in shortest way to the lake, the outer zone has crossing and pedestrian walk ways, finally the construction zone has internal permeable walk ways.

\section{Conclusion}

From the previous studies and analysis; first, there are three zones in the lake itself then its buffer which are three concentric zones that end in the construction zone (the outermost zone and the one having the most of land uses). Second, the green infrastructure techniques are very important to apply the idea of sustainable waterfront because of the direct relationship between green infrastructure principles and sustainable waterfront principles. Third, the analysis 


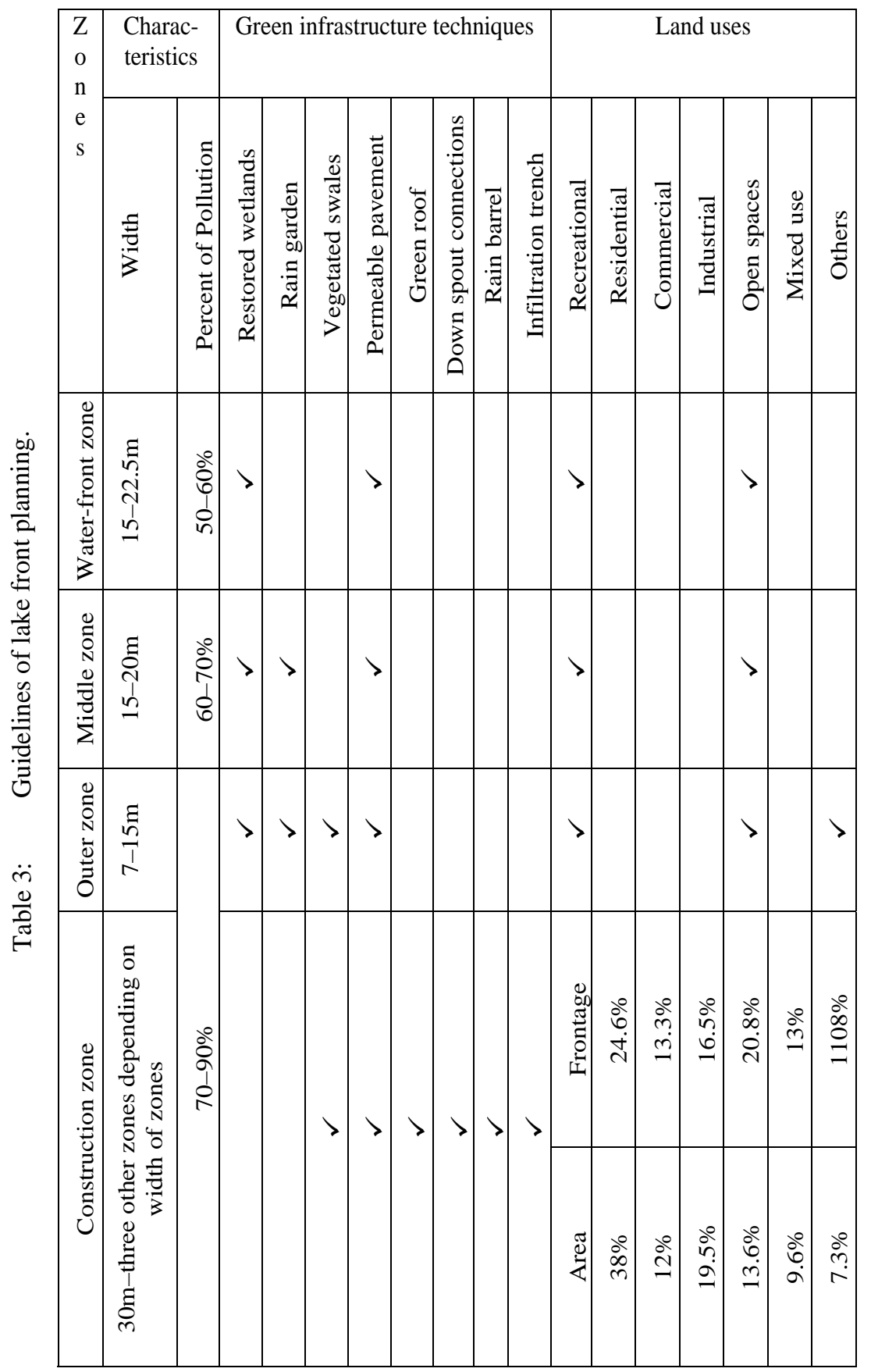


of land uses shows that the priority is for; open spaces with $54.5 \%$, then commercial $32.7 \%$, then residential with $7.2 \%$, finally others with $5.6 \%$. Finally comes the fourth point which is the guidelines of lake front planning; the characteristics of each water front zone, the green infrastructure techniques, land uses and the percentages of each zone according to the example of great lakes and the linking in each according to green linking, public transportation and pedestrian walkways.

\section{References}

[1] Brij gopal, M. Sengupta, R. Dalwani, and S.K. Srivastava, 2010. Conservation and management of lakes, ministry of environment and forest, government of India, New Delhi.

[2] Government of New Brunswick, 2013. http://www2.gnb.ca/content/gnb/en /departments/elg/environment/content/water/content/lakes/the_importance _oflakes.html

[3] Tangient LLC. Lake and ponds, 2013. www.msjuliansapes.wiki spaces.com/lakes+\%26+ponds.

[4] Index of content organism-environment, 2013. http://image.tutorvista.com /content/organisms-environment/

[5] Technology associates (TAIC), 2010. Guidelines for riparian and wetland buffers, City of Carlsbad Planning Department.

[6] Eric Williams, NH Department of Environmental Services, 2008. Innovative land use planning techniques, State of New Hampshire.

[7] Global conference on the urban future. Urban 21, Berlin, July 2000.

[8] Benedict, Mark A. and Edward T. McMahon. 2002. Green infrastructure: Smart Conservation for the $21^{\text {st }}$ Century. Washington, DC: Sprawl Watch Clearinghouse.

[9] Southeast Michigan Council of Governments. 2008. Planning with green infrastructure: An implementation resource of the new designs for growth guidebook. Michigan.

[10] Benedict, Mark A. and Edward T. McMahon. 2006. Green infrastructure: Linking Landscapes and Communities. Washington, DC: Island Press.

[11] National learning centre for private forest and range land owners. 2008. http://forestandrange.org/new_wetlands/recreation.htm

[12] Elizabeth Durfee, 2013. Planning and zoning the waterfront: Case studies from Michigan. Tacoma Washington, National Working Waterfronts and Waterways Symposium.

[13] Dill, P.M. and Bedford, P.J. 2001. Central waterfront part II plan. Making waves: Principles for building Toronto's waterfront. Toronto: Toronto Waterfront Revitalization Corporation.

[14] WATERFRONToronto, 2013. http://www.waterfrontoronto.ca/dbdocs /488f5cf44a20b.pdf 